\title{
PEMBELAJARAN FISIKA BERBASIS MASTERY LEARNING DAN REACT DALAM MENGOPTIMALKAN PENGUASAAN KONSEP
}

\author{
Faninda Novika Pertiwi \\ Dosen IAIN Ponorogo \\ faninda_novik@yahoo.com
}

\begin{abstract}
Abstrak
IPA merupakan salah satu mata kuliah wajib bagi PGMI, Namun mahasiswa PGMI tidak semuanya berasal dari lulusan SMA/SMK IPA. Oleh karena itu dalam mengajarkan IPA diperlukan konsep pembelajaran tertentu agar seluruh mahasiswa dapat menguasai konsepkonsep yang telah dipelajarinya. Pada penelitian ini akan diujikan keefektifan Mastery Learning dan REACT terhadap penguasaan konsep mahasiswa. Data yang dihasilkan dari penelitian ini adalah data penguasaan konsep mahasiswa yang telah mengalami pembelajaran Mastery Learning dan REACT selama 4 pertemuan berturut-turut. Hasil penelitian yang didapatkan berdasarkan hasil tes penguasaan konsep yaitu pembelajaran IPA dengan Mastery Learning lebih efektif daripada REACT. Analisis yang dilakukan yaitu dengan menggunakan ANAVA dan Uji lanjut yaitu Uji Scheffe. Berdasarkan hasil ANAVA diperoleh hasil $F_{\text {hitung }}>F_{\text {tabel }}$ yaitu 4,19> 4,04 sehingga disimpulkan bahwa terdapat perbedaan penguasaan konsep mahasiswa yang mengalami pembelajaran menggunakan Mastery Learning dengan mahasiswa yang mengalami pembelajaran menggunakan REACT. Selanjutnya, untuk mengetahui lebih efektif mana antara Mastery Learning dan REACT maka dilakukan uji lanjut yaitu uji Scheffe. Hasil uji Scheffe untuk penguasaan konsep mahasiswa menunjukkan bahwa t $(2,047)>t$ kritis $(2,009)$, maka Ho ditolak dan Ha diterima. Jadi pembelajaran IPA dengan Mastery Learning terbukti lebih efektif daripada pembelajaran IPA dengan REACT terhadap penguasaan konsep mahasiswa.
\end{abstract}

Kata Kunci: Penguasaan Konsep, Pembelajaran Fisika, Mastery Learning, REACT

\section{PENDAHULUAN}

Pembelajaran IPA merupakan salah satu pembelajaran yang mempunyai hubungan sangat erat dengan alam dan kehidupan manusia. Materi IPA berkaitan dengan biologi dan fisika, sehingga pembelajaran biologi maupun fisika yang diimplementasikan di kelas hendaknya juga sesuai dengan konsep pembelajaran IPA.

IPA merupakan salah satu mata kuliah wajib bagi mahasiswa di jurusan PGMI. Berkaitan dengan ke-IPA an, pada pembelajarannya, hendaknya menggunakan strategi yang bertujuan untuk meningkatkan kualitas pembelajaran menjadi lebih baik. Pada jurusan PGMI, mahasiswa berasal dari jurusan awal yang beragam, tidak semuanya berasal dari lulusan SMA/SMK IPA. Sebagian besar adalah berasal dari jurusan IPS dan agama. Hal inilah yang menjadi tantangan dalam mengajarkan IPA khususnya Fisika pada mahasiswa yang sebelumnya belum mengenal fisika. Oleh karena itu dalam pembelajarannya diperlukan konsep pembelajaran tertentu agar tujuan pembelajaran yang diinginkan dapat tercapai serta mahasiswa secara menyeluruh dapat menguasai konsepkonsep yang telah dipelajarinya.

Pada penelitian ini akan diujikan dua strategi pembelajaran, yaitu Mastery Learning dan REACT. Kedua strategi pembelajaran ini akan diujikan pada kelas PGMI, untuk mengetahui sejauh mana keefektifannya dalam mengoptimalkan penguasaan konsep mahasiswa. Kedua metode ini dipilih karena masing-masing punya kelebihan jika diterapkan pada kelas yang mahasiswanya heterogen. Keduanya juga sesuai dengan konsep pembelajaran yang konstruktivistik dan kontekstual. Mastery Learning dan REACT juga samasama merupakan strategi pembelajaran yang inovatif jika diterapkan dengan baik di kelas.

Mastery Learning merupakan konsep pembelajaran tuntas, yang dikembangkan oleh John B. Caroll dan Benjamin Bloom. 
Menurut Wena (2009), Belajar tuntas menyajikan suatu cara yang menarik dan ringkas untuk meningkatkan unjuk kerja siswa ke tingkat pencapaian suatu pokok bahasan yang lebih memuaskan. Strategi pembelajaran ini terdiri atas lima tahap, yaitu (a) orientasi (orientation), (b) penyajian (presentation), (c) latihan terstruktur (structured practice), (d) latihan terbimbing (guided practice), dan (e) latihan mandiri (independent practice). Pada Mastery Learning, maksud utamanya adalah memungkinkan $75 \%$ sampai $90 \%$ siswa untuk mencapai hasil belajar yang sama tingginya dengan kelompok terpandai dalam pengajaran klasikal. Pembelajaran tuntas sangat mengandalkan pada pendekatan tutorial dengan sesion-sesion kelompok kecil, tutorial orang perorang, pembelajaran terprogram, buku-buku ajar, permainan dan computer. Selain itu pembelajaran tuntas juga dapat digunakan untuk meningkatkan efisiensi belajar, meningkatkan minat belajar, dan meningkatkan sikap siswa yang positif terhadap bahan pelajaran yang dipelajarinya melalui metode-metode belajar dalam kesatuan kelas.

Mastery Learning yang akan diterapkan pada kelas PGMI ini, setiap mahasiswa diberikan kesempatan yang berbeda dalam kaitannya untuk memahami suatu materi. Kesempatan yang berbeda dalam hal ini misalnya, setiap mahasiswa diberikan alokasi waktu yang tidak sama dalam hal target memahami suatu materi atau dalam menyelesaikan suatu soal. Hal ini karena beragamnya jurusan awal mahasiswa yang ada di kelas PGMI. Mastery Learning ini dipilih untuk diujikan di kelas PGMI karena konsep pembelajaran tuntas yang diusung oleh pencetusnya. Setiap manusia mempunyai hak untuk mendapatkan pemahaman dan perlakuan yang sama maka meskipun ada sesuatu yang memang dibedakan antar mahasiswa tetapi ini semata-mata guna untuk mencapai tujuan pembelajaran yang maksimal dan menyeluruh.

Selain Mastery Learning, pada penelitian ini juga dipilih strategi REACT untuk diujikan keefektifannya terhadap pembelajaran fisika di kelas PGMI. Strategi
REACT merupakan strategi pembelajaran dengan pendekatan kontekstual yang ditawarkan oleh Center for Occupational Research and Development (CORD, 2003) di Amerika. Strategi REACT ini dikembangkan mengacu pada paham konstruktivisme karena pembelajaran dengan menggunakan strategi ini menuntut peserta didik untuk terlibat dalam aktivitas yang terus-menerus, berpikir dan menjelaskan penalaran mereka, mengetahui berbagai hubungan antara tema-tema dan konsep-konsep bukan hanya sekedar menghafal dan membaca fakta secara berulang-ulang serta mendengar ceramah dari pendidik. REACT merupakan singkatan dari Relating(menghubungkan), Experiencing (mengalami), Applying (mengaplikasikan), Cooperating (bekerja sama) dan Transferring (memindahkan). Melalui tahap-tahap tersebut, strategi REACT berpotensi untuk dapat meningkatkan kemampuan berpikir kreatif dan meningkatkan pemahaman siswa.

Berdasarkan uraian diatas, yaitu antara strategi Mastery Learning dan REACT yang sama-sama memiliki kelebihan serta samasama strategi yang mungkin dapat dijadikan alternatif mengajar pada kelas yang heterogen maka perlu diadakan penelitian untuk melihat keefektifan kedua strategi tersebut terhadap penguasaan konsep mahasiswa. Dengan mengetahui strategi mana yang lebih efektif maka pendidik tidak akan salah piih strategi dalam mengajarkan IPA di kelas PGMI. Melalui pemilihan strategi yang tepat diharapkan konsep yang dipelajari dapat diterima dengan baik oleh semua mahasiswa. Selain itu melalui penelitian yang akan dilakukan ini, direncanakan akan dihasilkan sebuah materi ajar yang didalam nya menggunakan strategi Mastery Learning dan REACT. Hal ini akan memudahkan dosen untuk melakukan pembelajaran di kelas pada saat materi yang sama dengan penelitian ini. Oleh karena itu penelitian ini penting untuk dilakukan.

\section{METODE PENELITIAN}

Jenis penelitian ini adalah quasi eksperiment dengan dua kelompok 
eksperimen tanpa kelas kontrol. Kelompok eksperimen pertama diberi perlakuan dengan pembelajaran Mastery Learning (dua kelas), sedangkan kelompok eksperimen kedua diberi perlakuan dengan pembelajaran REACT (dua kelas). Variabel bebas pada penelitian ini yaitu strategi Mastery Learning dan REACT. Sedangkan variabel moderatornya adalah kemampuan awal (sesuai jurusan ketika SMA/SMK/MAN), dan variabel terikatnya yaitu penguasaan konsep mahasiswa.

Penelitian ini dilakukan di jurusan PGMI IAIN Ponorogo pada semester genap 2017/2018. Populasi pada penelitian ini adalah seluruh mahasiswa jurusan PGMI IAIN Ponorogo konsentrasi IPA tahun pelajaran 2017/2018 yang terdiri dari 3 kelas. Sampel pada penelitian ini adalah dua kelas, Pemilihan sampel dilakukan secara acak dengan mengundi kelas yang ada. Satu kelas mengalami pembelajaran menggunakan strategi Mastery Learning dan satu kelas mengalami pembelajaran menggunakan strategi REACT.

Instrumen perlakuan yang digunakan pada penelitian ini adalah skenario pembelajaran mata kuliah IPA menggunakan strategi Mastery Learning dan skenario pembelajaran mata kuliah IPA menggunakan strategi REACT. Instrumen pengukuran yang digunakan pada penelitian ini adalah berupa tes tertulis. Jenis tes yang digunakan adalah butir soal essay untuk mengetahui penguasaan konsep mahasiswa.

Proses pengumpulan data pada penelitian ini adalah diawali dengan pemilihan dua kelas yang akan dijadikan kelas Mastery Learning dan kelas REACT. Pada akhir pembelajaran dilakukan tes pada masing-masing kelas menggunakan instrument pengukuran soal penguasaan konsep berbentuk essay. Data pemahaman konsep didapatkan dari hasil tes setelah perlakuan. Sebelum data dianalisis untuk menguji hipotesis yang telah diajukan terlebih dahulu maka perlu dilakukan uji prasyarat analisis. Uji prasyarat analisis terdiri dari uji homogenitas dan uji normalitas.

Uji normalitas digunakan untuk mengetahui data yang diperoleh terdistribusi normal atau tidak. Uji normalitas yaitu uji Lilliefors. Uji Lilliefors dilakukan dengan mencari $L_{\text {hitung, }}$ apabila $L_{\text {hitung }}<L_{\text {tabel }}$ maka sampel berdistribusi normal. Setelah dilakukan uji normalitas maka selanjutnya dilakukan uji homogenitas menggunakan Uji Barleth. Uji Barleth dilakukan dengan mencari harga $x$ hitung $^{2}$, jika $x_{\text {hitung }}{ }^{2}<x_{\text {tabel }}{ }^{2}$ maka kelompok data berasal dari populasi yang homogen. Setelah uji prasyarat dilakukan maka selanjutnya dilakukan uji Hipotesis, menggunakan Anava.

Uji Anava digunakan untuk menguji ada tidaknya perbedaan rata-rata antara kelompok satu dengan yang lain. Data yang akan diuji harus terdistribusi normal dan homogen. Berdasarkan hasil analisis, Jika $\mathrm{F}_{\text {hitung }}>\mathrm{F}_{\text {tabel}}$, maka Ha diterima dan Ho ditolak. Atau dapat dikatakan ada perbedaan antara kedua kelas yang diteliti. Uji Efektifitas dilakukan jika antara kedua rata-rata kelas terdapat perbedaan. Uji Efektifitas digunakan untuk mengetahui Efektifitas pembelajaran Mastery Learning dan REACT. Uji Efektifitas yang dipilih adalah Uji Scheffe. Rumus yang digunakan adalah sebagai berikut:

Rumus Uji Scheffe

$$
t=\frac{C}{\sqrt{\frac{2 K T G}{n}}}
$$

Rumus Nilai Kritis untuk Uji Scheffe

$$
t_{s}=\sqrt{(k-1) F_{(\alpha ;(k-1), v)}}
$$

Setelah nilai $\mathrm{t}$ dan $\mathrm{t}_{\text {kritis }}$ dihitung, maka dapat disimpulkan. Jika nilai t lebih besar daripada $t_{\text {kritis }}$ maka kedua kelas berbeda dan kelas X lebih efektif daripada kelas $\mathrm{Y}$ atau dapat dikatakan bahwa maka Ho ditolak, Ha diterima.

\section{HASIL PENELITIAN}

Berdasarkan penelitian yang telah dilakukan pada semester genap tahun akademik 2017/2018 di jurusan PGMI Fakultas Tarbiyah dan Ilmu Keguruan IAIN Ponorogo, diperoleh data berupa data kemampuan awal, data keterlaksanaan pembelajaran IPA menggunakan Mastery Learning, keterlaksanaan pembelajaran IPA menggunakan strategi REACT, Penguasaan 
konsep mahasiswa yang mengalami pembelajaran Mastery Learning dan yang mengalami pembelajaran REACT serta keefektifan Mastery Learning dan REACT dalam membelajarkan IPA di kelas PGMI.

Data kemampuan awal mahasiswa pada dua kelas yaitu kelas PGMI. IPA A dan kelas PGMI.IPA $\mathrm{C}$ yang diperoleh berdasarkan kuis yang diberikan pada awal perkuliahan dan berdasarkan jurusan awal ketika SMA/MA/SMK maka diperoleh hasil sebagai berikut.

Tabel 1. Hasil Kuis yang Diberikan di Awal Perkuliahan

\begin{tabular}{|l|c|c|}
\hline & $\begin{array}{l}\text { Kelompok } \\
\text { Mastery } \\
\text { Learning } \\
\text { (PGMI.IPA B) }\end{array}$ & $\begin{array}{l}\text { Kelompok } \\
\text { REACT } \\
\text { (PGMI. } \\
\text { IPA C) }\end{array}$ \\
\hline $\begin{array}{l}\text { Jumlah } \\
\text { Mahasiswa }\end{array}$ & 25 & 25 \\
\hline $\begin{array}{l}\text { Nilai } \\
\text { Tertinggi }\end{array}$ & 88 & 85 \\
\hline $\begin{array}{l}\text { Nilai } \\
\text { Terendah }\end{array}$ & 78 & 80 \\
\hline Rerata & 83.22 & 83.19 \\
\hline
\end{tabular}

Selain berdasarkan kuis, kemampuan awal penguasaan IPA dilihat berdasarkan jurusan ketika SMA/MA/SMK. Kelas PGMI.IPA B mahasiswa yang berasal dari jurusan awal SMA IPA 9 orang, yang berasal dari jurusan SMA IPS 6 orang, dan yang berasal dari jurusan MA Agama 2 orang dan SMK ada 8 orang. Sedangkan kelas PGMI IPA. C mahasiswa yang berasal dari SMA IPA ada 9 orang, yang berasal dari jurusan SMA IPS ada 6 orang, yang berasal dari MA/Agama 5 dan yang berasal dari SMK ada 5 orang.

Setelah data kemampuan awal diperoleh maka dilakukan uji normalitas menggunakan uji Liliefors. Hasil uji normalitas yang telah dilakukan dapat dilihat pada Tabel 2 berikut.

Tabel 2. Uji Normalitas Kemampuan Awal Mahasiswa

\begin{tabular}{|c|c|c|c|}
\hline Kelas & Lhitung & L tabel & Kesimpulan \\
\hline $\mathrm{X}$ & 0.0926 & 0.15662 & Normal \\
\hline $\mathrm{Y}$ & 0.1057 & 0.15662 & Normal \\
\hline
\end{tabular}

Tabel 2 menunjukkan bahwa data dari kedua kelas terdistribusi normal pada taraf signifikansi 0,05 .

Setelah uji normalitas, maka selanjutnya dilakukan uji homogenitas menggunakan uji Bartlet. Hasil uji homogenitas antara kedua kelompok yang telah dilakukan dengan uji Bartlet diperoleh hasil $x^{2}$ hitung $(1,053)<x^{2}(0,95 ; 1)=3,84$, sehingga dapat disimpulkan bahwa kedua kelompok data adalah homogen.

Selain data kemampuan awal, data yang diperoleh pada penelitian ini adalah data hasil observasi keterlaksanaan pembelajaran Mastery Learning dan REACT. Berdasarkan hasil observasi menunjukkan bahwa pembelajaran IPA menggunakan Mastery Learning dan REACT pada penelitian ini telah dilaksanakan dengan baik dan tahapan-tahapannya telah dilakukan semua. Setelah pembelajaran dilakukan kemudian diadakan tes untuk mengukur penguasaan konsep mahasiswa.

Penguasaan konsep mahasiswa pada penelitian ini diukur menggunakan tes penguasaan konsep berbentuk essay. Jumlah butir soal pada tes penguasaan konsep ini adalah delapan, yang berkaitan dengan materi perubahan wujud zat, perpindahan kalor, usaha dan gaya. Skor maksimal yang dapat dicapai mahasiswa adalah 100. Berdasarkan data yang didapatkan, rata-rata sekor penguasaan konsep mahasiswa lebih tinggi kelas yang mengalami pembelajaran Mastery Learning daripada kelompok yang mengalami pembelajaran REACT. Ringkasan hasil tes penguasaan konsep mahasiswa dapat dilihat pada Tabel 3 berikut.

Tabel 3. Ringkasan Hasil Tes Penguasaan Konsep Mahasiswa

\begin{tabular}{|c|c|c|c|}
\hline Kelas & $\begin{array}{l}\text { Nilai } \\
\text { Terendah }\end{array}$ & $\begin{array}{l}\text { Nilai } \\
\text { Tertinggi }\end{array}$ & $\begin{array}{l}\text { Rata- } \\
\text { Rata }\end{array}$ \\
\hline $\mathrm{X}$ & 67 & 92 & 79.16 \\
\hline $\mathrm{Y}$ & 64 & 87 & 75.12 \\
\hline
\end{tabular}


Berdasarkan Tabel 3 dapat dilihat bahwa nilai tes penguasaan konsep mahasiswa kelas Mastery Learning lebih tinggi daripada kelas $R E A C T$. Nilai rata-rata pada kedua kelas yaitu nilai 79,16 dan 75,12 , hal ini masuk dalam kategori baik. Sesuai dengan tabel penguasaan konsep bahwa jika nilai mahasiswa ada pada rentang $\geq 70-<80$ maka hal ini menunjukkan bahwa mahasiswa di kelas PGMI.IPA B dan PGMI.IPA.C menguasai sebagian besar konsep. Pada kelas Mastery Learning nilai terendah yaitu 67. Ini masuk ke dalam kriteria penguasaan konsep adalah cukup yang artinya adalah mahasiswa tersebut menguasai separuh konsep. Begitu pula pada kelas $R E A C T$, nilai terendah yaitu 64. Ini juga dalam kriteria penguasaan konsep masuk dalam kategori menguasai separuh konsep. Setelah data penguasaan konsep didapatkan, maka langkah selanjutnya yaitu melakukan uji normalitas dan uji homogenitas penguasaan konsep mahasiswa.

Uji normalitas pada penelitian ini dilakukan pada kelas X (Mastery Learning) maupun pada kelas Y (REACT) menggunakan uji Liliefors. Ringkasan uji normalitas data penguasaan konsep mahasiswa dapat dilihat pada Tabel 4 berikut.

Tabel 4. Ringkasan Hasil Uji Normalitas Data Penguasaan Konsep Mahasiswa

\begin{tabular}{|c|c|c|c|}
\hline Kelas & Lhitung $_{\text {L }}$ & L $_{\text {tabel }}$ & Kesimpulan \\
\hline $\mathrm{X}$ & 0.1592 & 0.15662 & Normal \\
\hline $\mathrm{Y}$ & 0.1514 & 0.15662 & Normal \\
\hline
\end{tabular}

Ringkasan hasil uji normalitas pada Tabel 4 di atas menunjukkan bahwa kedua kelas memiliki data yang terdistribusi normal.

Uji homogenitas pada penelitian ini dilakukan pada kelas Mastery Learning dan kelas REACT. Perhitungan uji homogenitas menggunakan uji Bartlet. Hasil perhitungan homogenitas menggunakan uji bartlet ini diperoleh hasil $x^{2}$ hitung $(3,80)<x_{(0,95 ; 1)}^{2}=$ 3,84 , dengan demikian kedua kelas adalah homogen.

Hipotesis yang dikemukakan pada penelitian ini adalah Pembelajaran IPA menggunakan Mastery Learning lebih efektif terhadap penguasaan konsep mahasiswa dibandingkan pembelajaran IPA menggunakan REACT. Sebelum menguji keefektifan pembelajaran terhadap penguasaan konsep mahasiswa, maka terlebih dahulu diuji apakah penguasaan konsep mahasiswa berbeda antara mahasiswa yang mengalami pembelajaran Mastery Learning dan mahasiswa yang mengalami pembelajaran dengan REACT. Uji yang digunakan yaitu ANAVA.

Hasil Ringkasan ANAVA untuk penguasaan konsep mahasiswa dapat dilihat pada Tabel 5 berikut.

Tabel 5. Ringkasan Hasil ANAVA Penguasaan Konsep Mahasiswa

\begin{tabular}{|l|l|l|l|l|}
\hline $\begin{array}{l}\text { Sumber } \\
\text { Keraga } \\
\text { man }\end{array}$ & $\begin{array}{l}\text { Jumlah } \\
\text { Kuadrat }\end{array}$ & $\begin{array}{l}\text { Der } \\
\text { ajat } \\
\text { Beb } \\
\text { as }\end{array}$ & $\begin{array}{l}\text { Kuad } \\
\text { rat } \\
\text { Teng } \\
\text { ah }\end{array}$ & $\begin{array}{l}\text { F } \\
\text { hitu } \\
\text { ng }\end{array}$ \\
\hline Kelas & 204,02 & 1 & $\begin{array}{l}204,0 \\
2\end{array}$ & \multirow{2}{*}{4,19} \\
\cline { 1 - 4 } $\begin{array}{l}\text { Galat } \\
\text { (Error) }\end{array}$ & 2336 & 48 & 48,67 & \\
\hline F tabel & & & & 4,04 \\
\hline
\end{tabular}

Berdasarkan hasil yang tertera pada Tabel 5 di atas nilai $F_{\text {hitung }}>F_{\text {tabel }}$ yaitu 4,19 $>$ 4,04 maka Ho ditolak dan Ha diterima. Sehingga dapat disimpulkan bahwa terdapat perbedaan penguasaan konsep mahasiswa antara mahasiswa yang mengalami pembelajaran menggunakan Mastery Learning dengan mahasiswa yang mengalami pembelajaran menggunakan REACT.

Hasil ANAVA menunjukkan adanya perbedaan penguasaan konsep mahasiswa yang disebabkan oleh perbedaan pembelajaran yang dilakukan, oleh karena itu akan dilakukan uji lanjut. Uji lanjut dilakukan untuk mengetahui pembelajaran mana yang lebih efektif terhadap penguasaan konsep mahasiswa. Uji lanjut yang digunakan pada penelitian ini adalah Uji Scheffe. adalah:

Hasil Uji Scheffe pada penelitian ini Taraf Nyata $\alpha=0,05$

Kontras Antar Kelas $(C)=79.16-75.12=$ 4,04 


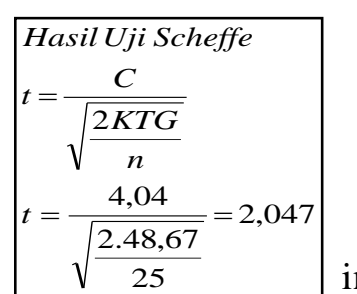

Hasil Nilai Kritis
$t_{s}=\sqrt{(k-1) F_{\alpha ;(k-1), v)}}$
$t_{s}=\sqrt{(2-1) 4,04}$
$t_{s}=2,009$

berdasarkan data penguasaan konsep mahasiswa adalah 2,047 sedangkan $\boldsymbol{t}$ kritis yang dihasilkan adalah 2,009. Berdasarkan hasil tersebut maka dapat disimpulkan bahwa: Hasil uji Scheffe untuk penguasaan konsep mahasiswa menunjukkan bahwa $\mathrm{t}$ $(2,047)>\mathrm{t}$ kritis $(2,009)$, maka Ho ditolak dan Ha diterima. Jadi pembelajaran IPA dengan Mastery Learning terbukti lebih efektif daripada pembelajaran IPA dengan REACT terhadap penguasaan konsep mahasiswa. Sehingga berdasarkan hasil uji Scheffe tersebut terlihat bahwa pembelajaran IPA di kelas PGMI B dengan Mastery Learning terbukti lebih efektif terhadap penguasaan konsep mahasiswa.

\section{PEMBAHASAN}

Pembelajaran Mastery Learning dilakukan pada kelas PGMI.IPA.B dan REACT pada kelas PGMI.IPA.C. Sebelum melakukan pembelajaran maka terlebih dahulu dibuat skenario pembelajaran, hal ini untuk memudahkan segala hal yang akan dilakukan di kelas. Pada pengambilan data pertemuan pertama, baik Mastery Learning maupun REACT materi yang akan dipelajari adalah perubahan wujud zat.

Pada pembelajaran Mastery Learning, sebelum membentuk mahasiswa menjadi kelompok-kelompok sesuai jurusan asal mahasiswa, peneliti menyampaikan apersepsi terkait perubahan wujud benda. Apersepsi yang dilakukan antara lain berkaitan dengan "Mengapa lama kelamaan jika es krim dikeluarkan dari lemari es maka kondisinya akan menjadi tidak sepadat saat masih di lemari es", Berdasarkan hal tersebut apakah es krim mengalami perubahan wujud? Jika iya mengapa demikian dsb". Melalui pertanyaan-pertanyaan yang diberikan pada saat apersepsi ini diharapkan kemampuan berpikir mahasiswa benar-benar digunakan dengan baik. Apersepsi ini pada Mastery Learning masuk pada tahapan Orientasi.
Pada tahap orientasi ini, peneliti membagi kelompok berdasarkan jurusan saat SMA/SMK/MAN. Ada 5 kelompok dalam kelas, 2 kelompok yang berasal dari IPS, ada 2 kelompok yang berasal dari IPA, dan ada 1 kelompok yang berasal dari SMK/Agama. Setiap kelompok wajib mendiskusikan tentang pengertian kalor, bagaimana kalor mampu merubah wujud zat, jenis perubahan wujud zat, dan contoh perubahan wujud zat yang melepas kalor dan menyerap kalor. Peneliti memberikan waktu yang sama kepada setiap kelompok untuk berdiskusi yaitu 20 menit. Jika dalam waktu 20 menit semua kelompok telah selesai, maka diskusi berakhir. Namun jika ada kelompok yang belum selesai, maka diberi tambahan waktu 5 menit. Pada pertemuan pertama ini yaitu materi perubahan wujud ada 2 kelompok yang belum selesai sehingga kelompok yang belum selesai tersebut didampingi agar semua materi telah tuntas untuk didiskusikan.

Setelah tahap orientasi maka tahap selanjutnya adalah tahap presentasi. Pada tahap presentasi ini peneliti memberikan kesempatan setiap kelompok untuk menyampaikan hasilnya maka setiap kelompok wajib presentasi. Teknik presentasi yang dilakukan adalah hasil diskusi setiap kelompok ditulis pada kertas manila kemudian ditempel pada dinding dekat tempat duduk mereka. Kemudian setiap anggota kelompok wajib menyampaikan hasil diskusi secara bergantian, jadi bukan hanya perwakilan kelompok yang presentasi. Kelompok yang tidak presentasi wajib berkomentar dan wajib bertanya pada kelompok yang presentasi. Kelompok yang presentasi wajib berusaha untuk memberikan penjelasan atas komentar dan pertanyaan yang diberikan oleh kelompok lain.

Setelah tahap presentasi maka selanjutnya adalah tahap latihan terstruktur. Pada tahap latihan terstruktur ini peneliti memberikan soal yang sama untuk semua kelompok. Waktu mengerjakan soal adalah 20 menit. Soal yang diberikan ini wajib dikerjakan bersama-sama dengan anggota kelompok agar selesai tepat waktu. Bagi kelompok yang belum selesai maka 
diberikan tambahan waktu dan diberikan bimbingan khusus.

Tahap selanjutnya adalah latihan terbimbing. Pada tahap ini peneliti membimbing kelompok yang belum selesai mengerjakan soal agar mampu menyelesaikan soal dengan baik. Jadi bagi kelompok yang telah selesai mengerjakan soal langsung dikoreksi jawabannya jika sudah memenuhi kriteria maka dianggap tuntas. Jika masih belum memenuhi kriteria maka wajib kembali merevisi jawaban yang masih salah melalui pembimbingan kembali. Kemudian pada tahap latihan terbimbing ini peneliti juga meminta setiap kelompok untuk melakukan percobaan sederhana yang berkaitan dengan peristiwa melebur, menguap, dan menyublim. Setiap kelompok melakukan percobaan lilin yang dinyalakan kemudian mengamati tetesan tetesan lilin, kemudian melakukan percobaan merebus air dalam panci kecil sampai mendidih dan ada uapnya, dan yang terakhir adalah mengamati kapur barus yang didiamkan beberapa saat, kapur barus menjadi kecil. Pada tahap latihan terbimbing ini, peneliti juga membimbing dan menjelaskan keterkaitan materi dengan percobaan sederhana yang dilakukan.

Konsep yang diharapkan muncul melalui pembelajaran ini adalah bahwa kalor dapat menyebabkan perubahan wujud benda yaitu melebur, membeku, menguap, mengembun, menyublim, dan mengkristal. Melalui tahapan-tahapan pada Mastery Learning semua mahasiswa tuntas mempelajari materi.

Pada pertemuan kedua materi yang dipelajari adalah perpindahan kalor. Tahapannya sama dengan pada pertemuan sebelumnya. Pada tahap orientasi, peneliti menyampaikan apersepsi terkait perpindahan kalor kemudian peneliti membentuk kelompok sesuai dengan kemampuan awal mereka. Mahasiswa diminta untuk mendiskusikan tentang pengertian kalor, cara perpindahan kalor dan contoh dari masing-masing cara perpindahan kalor secara konduksi, konveksi, dan radiasi. Pada pertemuan kedua ini tetap masih ada dua kelompok yang belum selesai mendiskuskan materi sesuai dengan waktu yang diberikan.
Tahap selanjutnya adalah tahap presentasi, kemudian masuk pada tahap latihan terstruktur. Setelah latihan terstruktur maka tahap selanjutnya adalah latihan terbimbing. Pada tahap ini peneliti membimbing kelompok yang belum selesai mengerjakan soal hal ini agar soal dapat diselesaikan dengan baik. Pada tahap latihan terbimbing ini peneliti juga meminta setiap kelompok untuk melakukan percobaan sederhana secara berkelompok. Kelompok 1 melakukan percobaan menyalakan lilin di lantai kemudian anggota kelompok mendekatkan tangannya disekitar lilin tersebut. Kelompok 2 melakukan percobaan merebus air di dalam mangkok, dan kelompok 3 melakukan percobaan memanaskan ujung kawat diatas lilin lalu merasakan ujung kawat yang satunya. Peneliti membimbing dan menjelaskan keterkaitan materi dengan percobaan sederhana yang dilakukan.

Tahap terakhir adalah latihan mandiri. Pada tahap ini peneliti memberikan soal tentang perpindahan kalor sebagai evaluasi akhir. Soal yang diberikan wajib dikerjakan secara mandiri dan secara individu. Hal ini untuk mengetahui materi yang telah dipelajari dapat diterima secara baik dan tuntas untuk setiap mahasiswa atau belum. Pada tahap latihan mandiri ini peneliti memberikan nomor sejumlah mahasiswanya, kemudian nomor tersebut dipasang di kepala, lalu peneliti memberikan pertanyaan dan menyebut nomor tertentu. Nomor yang disebut wajib untuk menjawab. Jika benar maka langsung dapat nilai tambahan jika salah maka tidak dapat nilai. Kesempatan ditunjuk tidak akan terulang sehingga ketika ditunjuk harus dimanfaatkan sebaik baiknya.

Konsep yang diharapkan muncul melalui pembelajaran Mastery Learning kedua ini adalah konsep kalor yaitu kalor merupakan suatu bentuk energi dan energi tidak dapat dimusnahkan tetapi dapat berpindah dan dapat berubah wujud. Kalor dapat berpindah melalui tiga cara yaitu konduksi, konveksi, dan radiasi. Konduksi yaitu peristiwa perpindahan kalor melalui zat perantara tanpa disertai perpindahan partikel-partikelnya (contoh : mengaduk teh panas, ujung sendok yang tidak tercelup ke 
dalam teh mula-mula dingin lama-lama terasa akan terasa panas). Konveksi yaitu peristiwa perpindahan kalor melalui zat perantara dengan disertai perpindahan partikel-partikelnya (contoh : merebus air). Radiasi yaitu peristiwa perpindahan kalor tanpa melalui zat perantara (contoh : panas matahari sampai di bumi). Konsep-konsep ini ternyata mampu dipahami mahasiswa lebih baik daripada pertemuan pertama meskipun ada dua kelompok yang perlu dipandu dalam menyelesaikan tugasnya.

Pada pertemuan ketiga materi yang dipelajari adalah usaha. Pada pertemuan ketiga ini mahasiswa sudah lebih terbiasa mengalami pembelajaran Pada pertemuan ketiga materi yang dipelajari adalah Usaha. Tahap pertama adalah tahap orientasi, pada tahap ini peneliti memberikan apersepsi yang terkait mobil yang mogok dijalan kemudian ada orang yang mendorong mobil, peneliti mengharapkan mahasiswa berpikir tentang orang yang mendorong mobil tersebut melakukan usaha atau tidak. Kemudian jika telah terjadi perbedaan pemikiran tentang usaha, peneliti membagi mahasiswa menjadi lima kelompok sesuai dengan kemampuan awal mahasiswa. Setiap kelompok wajib mendiskusikan tentang pengertian usaha dalam fisika dan usaha dalam kehidupan sehari-hari. Selain itu mahasiswa diminta mendiskusikan syarat-syarat seseorang dikatakan telah melakukan usaha dan tentang besarnya usaha pada arah gaya lurus terhadap perpindahan dan usaha pada arah gaya yang membentuk sudut terhadap perpindahan.

Tahap kedua yaitu tahap presentasi. Pada tahap ini peneliti memberi kesempatan setiap kelompok menyampaikan hasilnya maka setiap kelompok wajib untuk presentasi. Teknik presentasinya sama dengan pada materi 1 dan 2 . Setelah tahap presentasi maka tahap selanjutnya tahap latihan terstruktur kemudian tahap selanjutnya adalah latihan terbimbing. Pada tahap latihan terbimbing ini peneliti meminta setiap kelompok untuk melakukan percobaan sederhana yang berkaitan dengan usaha. Peneliti membagi mahasiswa menjadi 3 kelompok sesuai dengan kemampuan awal mahasiswa. Percobaan yang dilakukan yaitu menghitung usaha yang dilakukan untuk memindahkan tiga macam benda menggunakan neraca pegas. Tiga macam benda yang dipindahkan tersebut dapat mengalami 3 peristiwa, benda pertama tidak bergerak jika ditarik dengan neraca pegas, benda ke 2 berpindah searah dengan arah tarikan yang dilakukan, benda ke 3 berpindah ketika ditarik membentuk sudut terhadap arah perpindahannya. Peneliti kemudian membimbing dan menjelaskan keterkaitan materi dengan percobaan sederhana yang dilakukan.

Tahap terakhir adalah latihan mandiri. Pada tahap ini peneliti memberikan soal tentang usaha sebagai evaluasi akhir. Soal wajib dikerjakan secara mandiri dan secara individu. Hal ini untuk mengetahui materi yang telah dipelajari dapat diterima secara baik dan tuntas untuk setiap mahasiswa atau belum. Konsep yang diharapkan muncul pada materi ketiga ini adalah tentang deskripsi usaha dalam fisika dan usaha dalam kehidupan sehari-hari. Usaha dalam kehidupan sehari-hari merupakan segala sesuatu yang dilakukan manusia, usaha dalam fisika yaitu gaya yang dilakukan pada sebuah benda yang menyebabkan perpindahan.

Pada pertemuan terakhir pembelajaran Mastery Learning materi yang dipelajari adalah terkait Gaya. Tahap pertama yaitu Orientasi peneliti memberikan apersepsi yang berkaitan dengan gaya otot dan gaya gesek. Setelah apersepsi, peneliti membagi mahasiswa menjadi 3 kelompok sesuai dengan kemampuan awal yaitu jurusan asal. Setiap kelompok wajib mendiskusikan tentang gaya, khususnya tentang pengertian gaya, macam-macam gaya, syarat terjadinya gaya serta contoh penerapan gaya dalam kehidupan sehari-hari. Waktu diskusi yaitu 20 menit. Jika dalam waktu 20 menit semua kelompok telah selesai maka diskusi berakhir, namun jika ada kelompok yang belum selesai maka diberi tambahan waktu 5 menit. Jika masih belum selesai diberi tambahan waktu lagi dan kelompok yang belum selesai didampingi agar segera selesai dan semua materi telah tuntas untuk didiskusikan. Pada pertemuan terakhir ini semua kelompok selesai tepat waktu. 
Tahap selanjutnya yaitu presentasi dan latihan terstruktur. Teknik presentasi dan latihan terstruktur nya sama dengan pada pertemuan sebelumnya. Tahap berikutnya adalah latihan terbimbing. Pada tahap ini peneliti meminta setiap kelompok untuk melakukan percobaan sederhana yang berkaitan dengan usaha dan membagi mahasiswa menjadi 3 kelompok. Masingmasing kelompok diminta untuk membentuk lingkaran kemudian saling bergandengan tangan. Mahasiswa yang membentuk lingkaran diminta menggerakkan tangannya ke depan dan belakang sambil bernyanyi kemudian ketika 1 lagu selesai, maka diminta saling tarik menarik dengan temannya untuk bergerombol 3 orang. Bagi yang tidak mampu membentuk kelompok 3 orang maka mendapatkan hukuman untuk menjawab pertanyaan/bernyanyi. Kemudian lanjut bernyanyi lagi dan ketika 1 lagu selesai, maka diminta saling tarik menarik dengan temannya untuk bergerombol 4 orang dsb (harapannya adalah mereka merasakan adanya tarikan dan dorongan saat melakukan permainan itu sehingga akan mengetahui adanya gaya otot, dan adanya gaya gesek ketika sepatu mereka menyentuh lantai). Setelah permainan selesai mereka diminta duduk kembali. Lalu mereka diminta memperhatikan demonstrasi yang dilakukan peneliti ketika menjatuhkan gumpalan kertas dan penghapus secara bersamaan. Setelah itu peneliti membimbing dan menjelaskan keterkaitan materi dengan percobaan sederhana yang dilakukan.

Tahap terakhir dari Mastery Learning ini adalah latihan mandiri. Pada tahap ini peneliti memberikan soal tentang gaya sebagai evaluasi akhir. Tahap latihan mandiri yang dilakukan sama dengan pertemuan sebelumnya.

Konsep yang diharapkan muncul pada pembelajaran Mastery Learning terakhir ini adalah tentang gaya pada fisika. Gaya dalam fisika merupakan suatu tarikan atau dorongan. Beberapa jenis gaya antara lain gaya otot, gaya gesek, dan gaya gravitasi. Contoh penerapan gaya otot adalah ketika seseorang menarik atau mendorong suatu benda. Sedangkan contoh penerapan gaya gesek adalah jika ada dua buah benda yang saling bersentuhan kemudian bidangnya adalah kasar, sedangkan contoh penerapan gaya gravitasi adalah benda yang jatuh arahnya selalu ke bawah

Pada saat kelas PGMI.IPA.B mengalami pembelajaran Mastery Learning maka kelas PGMI.IPA.C mengalami pembelajaran REACT. Pengambilan data untuk pembelajaran menggunakan strategi REACT ini sesuai dengan jadwal mata kuliah metodologi pembelajaran IPA pada kelas PGMI IPA.C. Peneliti mengamati kegiatan mahasiswa ketika mengalami pembelajaran menggunakan REACT. Pada pertemuan pertama, peneliti meminta mahasiswa untuk perkenalan sekaligus menyebutkan jurusan asal saat di SMA/MA/SMK. Kemudian peneliti menanyakan alsan yang berkaitan dengan ketertarikan mahasiswa memilih konsentrasi IPA. Setelah itu, peneliti memberikan kuis yang berhubungan dengan materi IPA yang akan dipelajari selama satu semester. Hal ini dilakukan untuk mengetahui kemampuan awal mahasiswa. Selanjutnya pada pertemuan berikutnya peneliti langsung melakukan pembelajaran dengan strategi REACT. Dimana tahapannya adalah Relating, Experiencing, Applying, Cooperating, dan Transferring. Sebelum melakukan pembelajaran maka terlebih dahulu dibuat skenario pembelajaran, hal ini untuk memudahkan segala hal yang akan dilakukan di kelas.

Pada pengambilan data pertemuan pertama menggunakan REACT, materi yang akan dipelajari adalah perubahan wujud zat. Tahap pertama pembelajaran REACT adalah Relating. Pada tahap Relating ini peneliti mengkaitkan materi dengan dunia nyata melalui apersepsi tentang perubahan wujud zat. Pertanyaan yang disampaikan peneliti misalnya tentang mengapa daun terlihat basah pada pagi hari. Kemudian setelah tahap relating maka tahap selanjutnya adalah Experiencing. Pada tahap ini peneliti mengajak mahasiswa untuk mencoba sesuatu (mengalami sendiri) untuk menggali kemampuan awal mahasiswa. Peneliti membawa gelas berisi teh panas dan tutup gelas, kemudian meminta mahasiswa untuk meletakkan 
tangannya diatas uap yang keluar dari teh panas tersebut lalu meminta mahasiswa untuk menutup teh panas tersebut dengan tutup gelas yang telah disediakan. Kemudian peneliti meminta mahasiswa untuk mengamati dan menanggapi kenapa bagian luar gelas basah.

Tahap selanjutnya setelah Experiencing yaitu tahap Applying. Pada tahap ini peneliti mengajak mahasiswa untuk menerapkan konsep-konsep yang telah dipelajari. Peneliti membagi mahasiswa menjadi 3 kelompok, kelompok 1 melakukan percobaan lilin yang dinyalakan kemudian mengamati tetesan tetesan lilin, kelompok 2 melakukan percobaan merebus air dalam wadah kecil, setelah mendidih akan tampak ada uap dan gelembung-gelembung pada air tersebut, kelompok 3 melakukan percobaan kapur barus yang didiamkan beberapa saat, kapur barus menjadi kecil. Kemudian tahap selanjutnya yaitu Cooperating, peneliti meminta mahasiswa untuk belajar kelompok untuk saling berbagi pengetahuan. Peneliti meminta mahasiswa berdiskusi untuk membahas percobaan yang telah dilakukan, dan menghubungkannya dengan perubahan wujud zat. Tahap terakhir yaitu Transferring, pada tahap ini peneliti memberikan permasalahan berbeda tetapi masih terkait dengan konsep yang telah dipelajari mahasiswa. Permasalahan yang diberikan yaitu tentang bagaimana proses pembuatan garam dan dalam proses pembuatan garam tersebut terdapat proses perubahan wujud apa saja yang dialami air laut hingga menjadi garam. Kemudian jawaban dari permasalahan yang diberikan disampaikan di depan kelas. Kemudian pada tahap ini peneliti memberikan saran dan penguatan.

Pada pembelajaran REACT yang kedua materi yang dipelajari adalah perpindahan kalor. Pada tahap pertama yaitu Relating, peneliti mengkaitkan materi dengan dunia nyata melalui apersepsi tentang perpindahan kalor. Peneliti mengajak mahasiswa menuju luar ruangan, mahasiswa diajak berjemur sebentar. Mahasiswa ditanya tentang apa yang dirasakan setelah berjemur, kemudian peneliti mendengarkan jawaban atau tanggapan dari mahasiswa. Setelah itu peneliti kembali bertanya kepada mahasiswa tentang minuman hangat yang ditaruh didalam gelas. Ketika bagian luar gelas dipegang mengapa akan terasa hangat. Kemudian ketika sedang merebus air mengapa airnya berubah menjadi ada gelembung-gelembungnya ketika mendidih. Berdasarkan pertanyaan-pertanyaan pada apersepsi tersebut peneliti menampung jawaban atau tanggapan dari mahasiswa baik yang benar maupun yang masih kurang tepat.

Tahap selanjutnya yaitu Experiencing, peneliti mengajak mahasiswa untuk mencoba sesuatu (mengalami sendiri) untuk menggali kemampuan awal mahasiswa. Peneliti membawa gelas berisi teh panas, kemudian meminta dua orang mahasiswa untuk mengaduk teh tersebut dengan sendok logam, yang satunya mengaduk dengan menggunakan sendok kayu. Kemudian peneliti meminta mahasiswa untuk mengamati dan menanggapi apa yang telah diamati atau dialaminya.

Tahap selanjutnya yaitu Applying, pada tahap ini peneliti mengajak mahasiswa untuk menerapkan konsep-konsep yang telah dipelajari. Peneliti meminta mahasiswa untuk melakukan percobaan sederhana di kelas. Mahasiswa dibagi menjadi 3 kelompok. Kelompok 1 melakukan percobaan menyalakan lilin di mangkuk kemudian anggota kelompok mendekatkan tangannya disekitar lilin tersebut. Kelompok 2 melakukan percobaan merebus air di dalam mangkok. Kelompok 3 melakukan percobaan memanaskan ujung kawat diatas lilin, merasakan ujung kawat yang satunya. Setelah tahap Applying dilanjutkan tahap Cooperating. Pada tahap ini peneliti meminta mahasiswa untuk belajar kelompok untuk saling berbagi pengetahuan. Peneliti juga meminta mahasiswa berdiskusi untuk membahas kegiatan percobaan yang telah dilakukan, menghubungkannya dengan perpindahan kalor.

Tahap terakhir yaitu Transferring. Tahap ini merupakan tahap dimana kemampuan sesuangguhnya dari tiap mahasiswa dapat dinilai. Karena pada tahap ini peneliti memberikan permasalahan 
berbeda tetapi masih terkait dengan konsep yang telah dipelajari mahasiswa. Permasalahan yang diberikan pada tahap ini misalnya tentang mengapa memakai pakaian gelap pada siang hari akan terasa lebih panas daripada memakai pakaian berwarna terang. Kemudian, mahasiswa juga diminta menceritakan proses terjadinya angin darat dan angin laut dan mengkaitkan hubungannya dengan peristiwa konveksi. Setelah permasalahan ini diselesaikan, maka peneliti meminta mahasiswa menyampaikan hasil diskusi di depan kelas, meminta saran dan pendapat kelompok lain dan yang terakhir peneliti memberikan penguatan atas materi yang telah dipelajari.

Materi ketiga yang dipelajari dengan pembelajaran REACT adalah materi Usaha. Pada tahap pertama yaitu Relating peneliti mengkaitkan materi dengan peristiwa sehari-hari. Pertanyaan yang disampaikan peneliti antara lain tentang mobil yang mogok dijalan kemudian ada beberapa orang yang mendorong mobil, dari hal tersebut mahasiswa diminta memberikan tanggapan apakah yang dilakukan beberapa orang tersebut dikatakan telah melakukan usaha atau tidak. Tahap kedua adalah Experiencing, pada tahap ini peneliti mengajak mahasiswa untuk mencoba sesuatu (mengalami sendiri) dengan tujuan untuk menggali kemampuan awal mahasiswa. Peneliti meminta 3 mahasiswa untuk maju ke depan kelas. mahasiswa 1 diminta untuk mendorong kursi (kursi bergerak), mahasiswa 2 diminta untuk mendorong meja (meja tidak bergerak), mahasiswa 3 diminta untuk mendorong tembok (tembok tidak bergerak). Lalu ketiga mahasiswa tersebut diminta untuk bersama-sama mendorong tembok (tembok tetap tidak bergerak). Kemudian peneliti meminta mahasiswa untuk mengamati dan menanggapi apa yang telah diamati atau dialaminya serta menghubungkannya dengan konsep usaha.

Tahap selanjutnya yaitu Applying. Pada tahap ini peneliti mengajak mahasiswa untuk menerapkan konsep-konsep yang telah dipelajari. Peneliti juga meminta mahasiswa untuk melakukan percobaan sederhana di kelas. Mahasiswa dibagi menjadi 3 kelompok. Percobaan yang dilakukan yaitu menghitung usaha yang dilakukan untuk memindahkan tiga macam benda menggunakan neraca pegas. Tahap selanjutnya yaitu tahap Cooperating. Pada tahap ini peneliti meminta mahasiswa untuk belajar kelompok untuk saling berbagi pengetahuan. Meminta mahasiswa berdiskusi untuk membahas kegiatan percobaan yang telah dilakukan, menghubungkannya dengan konsep usaha. Tahap terakhir yaitu Transferring. Pada tahap ini peneliti memberikan permasalahan berbeda tetapi masih terkait dengan konsep yang telah dipelajari mahasiswa. Permasalahan yang diberikan antara lain adalah tentang lebih mudah mana menaiki tangga yang sudut kemiringannya besar atau yang kecil. Kemudian permasalahan tentang tujuan jalan di pegunungan dibuat berkelok-kelok, serta kaitannya dengan konsep usaha. Setelah permasalahan selesai dipecahkan, maka peneliti meminta mahasiswa menyampaikan hasil diskusi di depan kelas, meminta saran dan pendapat kelompok lain. Setelah semua tahapan selesai maka peneliti memberikan penguatan atas materi yang telah dipelajari pada hari tersebut.

Materi terakhir pada pembelajaran REACT ini adalah Gaya. Pada materi kali ini, pada tahap apersepsi peneliti menggali kemampuan awal mahasiswa melalui pertanyaan yang berhubungan dengan gaya otot dan gaya gesek. Pertanyaan yang disampaikan peneliti antara lain yaitu ketika seseorang mengayuh sepeda, apakah di kaki terasa seperti ada tarikan pada otot-ototnya. Kemudian ketika seseorang sedang mengangkat beban yang berat, apakah tangan terasa ada tarikan. Kemudian yang terakhir adalah ketika berjalan ataupun naik kendaraan, ketika sandal atau ban bersentuhan dengan aspal mengapa mampu berjalan dengan baik dan tidak tergelincir.

Tahap selanjutnya adalah tahap Experiencing. Pada tahap ini peneliti mengajak mahasiswa untuk mencoba sesuatu (mengalami sendiri) untuk menggali kemampuan awal mahasiswa. Peneliti kemudian meminta 4 mahasiswa untuk maju ke depan kelas. 2 mahasiswa diminta untuk mendorong meja dan menarik meja, 1 mahasiswa diminta untuk 
menjatuhkan penghapus, 1 mahasiswa diminta untuk menggosok-gosokkan kedua telapak tangannya sampai terasa hangat. Kemudian peneliti meminta mahasiswa untuk mengamati dan menanggapi apa yang telah diamati atau dialaminya.

Tahap selanjutnya adalah tahap Applying. Pada tahap ini peneliti mengajak mahasiswa untuk menerapkan konsepkonsep yang telah dipelajari. Peneliti meminta mahasiswa untuk membentuk lingkaran kemudian saling bergandengan tangan, dan ada satu mahasiswa yang membawa bola dari gumpalan kertas. Mahasiswa yang membentuk lingkaran diminta menggerakkan tangannya ke depan dan belakang sambil bernyanyi kemudian ketika 1 lagu selesai, maka diminta saling tarik menarik dengan temannya untuk bergerombol 5 orang. Kemudian lanjut bernyanyi lagi dan ketika 1 lagu selesai, maka diminta saling tarik menarik dengan temannya untuk bergerombol 6 orang. dsb (harapannya adalah mereka merasakan adanya tarikan dan dorongan saat melakukan permainan itu sehingga akan mengetahui adanya gaya otot, dan adanya gaya gesek ketika sepatu mereka menyentuh lantai). Setelah tahap Applying ini tahap selanjutnya adalah Cooperating. Pada tahap ini peneliti meminta mahasiswa untuk belajar kelompok untuk saling berbagi pengetahuan. Peneliti juga meminta mahasiswa untuk mendiskusikan kira-kira gaya apa saja yang dialami ketika melakukan permainan pada tahap applying.

Tahap terakhir pada pembelajaran REACT ini adalah Transferring. Pada tahap ini peneliti memberikan permasalahan berbeda tetapi masih terkait dengan konsep yang telah dipelajari mahasiswa. Permasalahan-permasalahan yang disampaikan peneliti antara lain berkaitan tentang mengapa bumi dan planet-planet yang dapat berputar sesuai garis edarnya, kira-kira apa yang menyebabkan bisa demikian. Kemudian mengapa manusia dan benda-benda yang ada di bumi dapat seimbang berdiri di atas tanah, Gaya apa yang mempengaruhinya dsb. Jika permasalahan tersebut telah selesai dikerjakan maka peneliti meminta mahasiswa menyampaikan hasil diskusi di depan kelas, kemudian meminta saran dan pendapat kelompok lain. Pada tahap akhir peneliti memberikan penguatan atas materi yang telah dipelajari

Berdasarkan uraian data diatas, pada data keterlaksanaan pembelajaran, tampak bahwa kedua pembelajaran telah dilakukan dengan sangat baik. Pada kelas Mastery Learning maupun REACT sama-sama menghasilkan persentase yang baik. Keberhasilan pelaksanaan pembelajaran ini juga didukung dengan jawaban-jawaban angket yang diberikan di akhir perkuliahan. Salah satu pertanyaan yang diberikan kepada mahasiswa hanya sederhana yaitu tentang bagaimana pendapat mahasiswa tentang penerapan dan langkah-langkah dari pembelajaran menggunakan Mastery Learning dan pembelajaran menggunakan REACT.

Hasil angket yang diberikan mahasiswa hampir seluruhnya menyatakan bahwa Mastery learning ini efektif jika diterapkan dalam pembelajaran sehari-hari karena dalam tahap pembentukan kelompok awal sudah dibagi berdasarkan jurusan ketika di MA/SMA/SMK sehingga dari awal kelompok tersebut memiliki cara atau tingkat berpikir sama atas materi yang disampaikan pendidik. Selain itu, mahasiswa berpendapat bahwa Mastery Learning efektif diterapkan di kelas karena mengingat bahwa mahasiswa PGMI tidak semuanya berasal dari jurusan awal yang sama. Namun, semuanya dituntut mampu menguasai konsep IPA. Sehingga sangat cocok jika Mastery Learning ini diterapkan di kelas heterogen karena konsep pembelajaran tuntas nya yaitu menyajikan suatu cara pembelajaran yang menarik kemudian memberikan waktu tambahan jika memang ada yang belum tuntas kemudian ada pendampingan bagi kelompok yang masih bingung. Hal ini dilakukan dengan tujuan agar semua mahasiswa mampu mendapatkan hasil belajar yang maksimal.

Meskipun berdasarkan analisis data, REACT masih kalah efektif jika dibandingkan dengan Mastery Learning namun REACT tetap dapat dijadikan pilihan dalam mengajarkan IPA. Keunggulan REACT adalah dalam setiap tahapannya 
mahasiswa diajak untuk berpikir, membayangkan suatu peristiwa kemudian mengalami sendiri lalu melakukan suatu percobaan sederhana dan yang terakhir menyelesaikan permasalahan dalam kehidupan sehari-hari yang berhubungan dengan materi. Melalui tahapan ini konsep mampu dikuasai mahasiswa melalui penemuan dan pembuktian yang mereka lakukan sendiri sehingga konsep-konsep yang dihasilkan akan bertahan lama. Namun, karena di REACT ini pembelajarannya tidak memperhatikan jurusan awal mahasiswa maka REACT ini masih kurang efektif jika dibandingkan dengan kelas Mastery Learning.

Kelas PGMI memang sangat heterogen sehingga tidak semua model pembelajaran cocok diterapkan di kelas tersebut. Keunggulan Mastery Learning ini adalah memberikan waktu atau kesempatan lebih bagi yang belum menyelesaikan tugas maupun yang belum memahami materi yang sedang dibahas. Karena memang harapannya semua mahasiswa akan mampu mencapai hasil belajarnya dengan baik dan konsep dapat dikuasai secara maksimal.

Hal ini sesuai dengan pernyataan Kunandar (2007), bahwa belajar tuntas adalah suatu sistem belajar yang menginginkan sebagian besar peserta didik dapat menguasai tujuan pembelajaran secara tuntas. Hal ini mengindikasikan bahwa mahasiswa termotivasi untuk mengikuti materi dan mahasiswa lebih mudah menguasai konsep. Konsep akan lebih mudah dipahami melalui penggunaan lembar latihan terbimbing dan latihan mandiri. Tahap latihan terbimbing dan latihan mandiri ini membuat mahasiswa lebih terarah untuk memahami materi dan menguasai konsep.

Berdasarkan penelitian yang telah dilakukan, maka proses belajar yang berorientasi pada Mastery Learning ini harus dimulai dengan penguasaan (Mastery)

\section{DAFTAR PUSTAKA}

Makmun, Abin Syamsudin. Psikologi Pendidikan. 1999. Bandung: PT.Rosda Karya. bagian terkecil, kemudian baru dapat dilanjutkan ke unit berikutnya. Jadi, seseorang dapat dikatakan menguasai suatu konsep yaitu apabila seseorang tersebut mempelajari unit tertentu kemudian baru berpindah mempelajari unit yang lain jika seseorang tersebut menguasai sekurangkurangnya $75 \%$ dari kompetensi dasar yang diharapkan (Makmun, 1999).

\section{SIMPULAN}

Berdasarkan hasil penelitian yang dilakukan dapat diperoleh kesimpulan sebagai berikut: (1) Penguasaan konsep mahasiswa jurusan PGMI yang mengalami pembelajaran IPA dengan Mastery Learning berdasarkan nilai rata-rata tes yang dihasilkan adalah 85 . Hal ini sesuai dengan pedoman tingkat penguasaan konsep mahasiswa, yaitu ada pada kategori sangat baik. Berarti hal ini menunjukkan bahwa mahasiswa PGMI yang mengalami pembelajaran Mastery Learning hampir menguasai seluruh materi yang ada; (2) Penguasaan konsep mahasiswa jurusan PGMI yang mengalami pembelajaran IPA dengan REACT berdasarkan nilai rata-rata tes yang dihasilkan adalah 80 . Hal ini sesuai dengan pedoman tingkat penguasaan konsep mahasiswa, yaitu ada pada kategori sangat baik. Berarti hal ini menunjukkan bahwa mahasiswa PGMI yang mengalami pembelajaran REACT hampir menguasai seluruh materi yang ada; (3) Penguasaan konsep mahasiswa PGMI yang mengalami pembelajaran IPA dengan Mastery Learning lebih tinggi jika dibandingkan dengan mahasiswa PGMI yang mengalami pembelajaran IPA dengan REACT. Secara rata-rata penguasaan konsep mahasiswa PGMI yang mengalami pembelajaran IPA dengan Mastery Learning lebih tinggi 5 poin jika dibandingkan dengan mahasiswa PGMI yang mengalami pembelajaran dengan

REACT

Azizahwati. Penerapan Strategi Mastery Learning Untuk Mendiskripsikan Hasil Belajar Mahasiswa Program Studi Pendidikan Fisika FKIP UNRI Pada Mata Kuliah Fisika Matematika 1. Jurnal Geliga Sains. Volume (3) 2. 
CORD. 2003. The REACT Strategi.(online),(http: www.texascollaborate.org/The REACT Strategi.htm) diakses 11 Oktober 2017.

Crawford, Michael. 2001. Contextual Teaching and Learning: Strategies for Creating Constructivist Classrooms (Conclusion), CONNECTIONS, Volume 11, Number 9 , http://www.cord.org/uploadedfiles/Vol . 11 No. 9.pdf diakses tanggal 10 Oktober 2017.

Dahar, Ratna Wilis. 2006. Teori-Teori Belajar dan Pembelajaran. Bandung: Erlangga.

Depdiknas. Kurikulum Berbasis Kompetensi : Konsep, Karakteristik, dan Implementasi. 2001.

Hamalik, Oemar. 2001. Pendekatan Baru Strategi Belajar Mengajar Berdasarkan CBSA. Bandung: Sinar Baru Algesindo.

Ichsan. 2007. Prinsip Pembelajaran Tuntas Mata Pelajaran PAI. Jurnal Pendidikan Agama Islam. Volume IV.

Muslich, Masnur. 2008. KTSP Pembelajaran Berbasis Kompetensi dan Kontekstual. Jakarta: Bumi Aksara.

Rita Lefrida. 2010. Efektifitas Penerapan Pembelajaran Kontekstual Dengan Strategi REACT (Relating, Experiencing, Applying, Cooperating, dan Transferring) Untuk
Meningkatkan Pemahaman Pada

Materi Logika Fuzzy.

Rahayu, Sri. 2004. Pembelajaran Kimia dengan Pendekatan Kontekstual. Makalah Disajikan dalam Workshop Sosialisasi dan Implementasi Kurikulum Berbasis Kompetensi di Madrasah Aliyah Universitas Negeri Malang. Malang 13-17 Januari.

Satria, Ahmad. 2005. Kamus Besar Bahasa Indonesia. Jakarta: Halim Jaya.

Santrock, W. J. 2008. Psikologi Pendidikan. Jakarta: Kencana Prenada Media Group.

Sugiyono. 2010. Statistika Untuk Penelitian. Bandung: Alfabeta.

Suparno, Paul. 2003. Miskonsepsi Dan Perubahan Konsep Dalam Pendidikan Fisika (Jakarta: Gramedia Widiasarana).

Suparno, Paul. 2013. Metodologi Pembelajaran Fisika, Konstruktivistik dan Menyenangkan. Yogyakarta: Universitas Sanata Dharma.

Suyono \& Hariyanto. 2012. Belajar dan Pembelajaran : Teori dan Konsep. Surabaya: Rosda.

Usman, Moh. Uzer dan Setiawati, Lilis. 1993. Upaya Optimalisasi Kegiatan Belajar Mengajar. Bandung: Remaja Rosdakarya.

Wena, M. 2009. Strategi Pembelajaran Inovatif Kontemporer. Bumi Aksara, Jakarta. 